\title{
FUNCTIONING OF THE SYSTEM OF COMPREHENSIVE ANALYSIS OF THE ACTIVITY OF THE PRODUCTION ENTERPRISE
}

\section{ФУНКЦІОНУВАННЯ СИСТЕМИ КОМПЛЕКСНОГО АНАЛІЗУ ДІЯЛЬНОСТІ ВИРОБНИЧОГО ПІДПРИЕМСТВА}
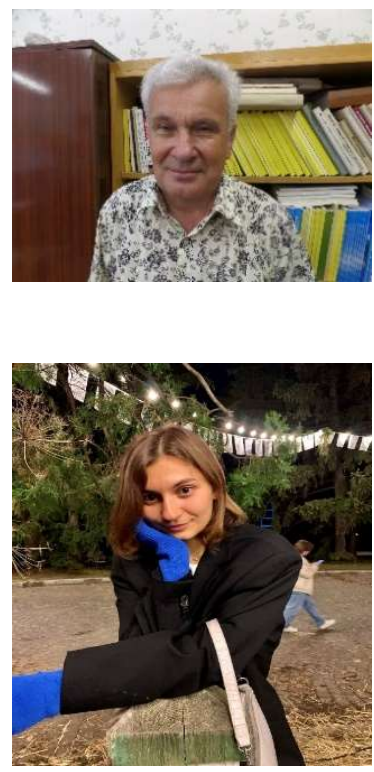

Lykhostup M., Candidate of Technical Sciences, Associate Professor, Associate Professor, Department of Transportation Construction and Property Management, National Transport University.e-mail: lichostup5n5@gmail.com, tel. +380662363038, Ukraine, 01010, Kyiv, vul. Omeljanovicha-Pavlenka, 1, room 206. https://orcid.org/0000-0001-8139-1768

Gorban I., student of speciality for business, commerce and exchange activity, Department of Transportation Construction and Property Management, National Transport University. e-mail: irka.gorban@gmail.com, tel. +380668300232, Ukraine, 01010, Kyiv, vul. Omeljanovicha-Pavlenka, 1, room 206.

https://orcid.org/0000-0002-1254-4772

Abstract. The article considers the basics of the system of complex analysis of the enterprise engaged in transport construction, which is proposed to be implemented in three stages. The idea of allocating such stages determines the needs of the enterprise in obtaining decisions not only about the current shortcomings in its activities, but also about the positive directions of its development. At each stage of the analysis, it is proposed to use relatively simple, but effective and accessible to employees of the enterprise methods. The first, which is generally presented as a rapid analysis, uses relatively simple expert methods. At the second stage, when it comes to the analysis of current activities of the enterprise, it is recommended to use calculation and analytical methods, which are developed in official methods and recommendations. The third stage is the stage of conducting scientific and practical work and research, which are aimed at obtaining important decisions in the field of significant change and improvement of the enterprise. Each stage of the analysis of activity of the enterprise is shown in article by examples of the decision of its component problems.

Key words: enterprise, complex analysis, stages, methods, decision algorithms.

\section{Introduction}

The analysis of the production enterprise, which independently fulfills contracts in the field of construction and operation of transport facilities (DBU, companies, joint-stock companies, etc.), is the final function of the management system. Evaluation of the advantages of its activities in comparison with other enterprises and identification of shortcomings can be established only in the process of conducting various types of analysis. But a sample analysis of only some activities can lead to misinterpretation of the development of the enterprise as a whole, and therefore it is proposed to implement this function in a comprehensive system that includes a number of stages and uses different methods. The first stage is a rapid analysis of activities based on the implementation of expert methods. It is recommended to include in the questionnaire of the expert survey the 
characteristic factors that characterize different types of activity - production, technological, economic, organizational and financial. The second stage is an analysis of the most important factors that determine the characteristics of the enterprise and which were identified in the first stage. This stage of analysis can be defined as a system of implementation of calculation - analytical methods aimed at obtaining data that characterize the prospects and dynamics of development of a particular activity of the enterprise. At the third stage with the use of special scientific search methods a thorough study of the causes and consequences of the obtained values of individual indicators. For this purpose special calculations, statistical researches are used, and also scientific - search works are carried out. Such a detailed, causal, order of analysis of various activities of the enterprise allows to identify weaknesses and make recommendations on the forecast of their liquidation.

\section{Presenting main material}

When imagining the concept of "analysis", as a rule, there is an idea of the implementation of decisions about the current state of the object and the search for its improvement using possible information and certain methods. Developed mathematical methods of analysis of the state of objects mainly reflect the procedures of processing arrays of information, most of which are quite complex for operational use by employees in their activities. In recent decades, the solution of problems of analysis of the state of objects is proposed in the framework of system analysis, which is a set of methods and tools (usually information technology) used to learn the processes of object development, which are reflected in the sequence of actions to determine the best "links between variable or constant elements of the system." In most cases, such methods and tools are based on the use of complex mathematical apparatus and specific definitions, such as utility functions, multicriteria solutions, etc., which makes them remote or not suitable for solving practical problems of enterprise analysis. On the other hand, practically available methods of analysis of the enterprise [1], as a rule, are focused on assessing its financial condition, which is generally reduced to the procedures of operating with accounting information.

But when we really consider the system of enterprise activity as a set of interconnected subsystems that form the production, organizational, technological, economic and financial activities of the enterprise during certain periods (for example, five years, years, terms of individual contracts), it is possible to conclude that the analysis of the enterprise should be developed according to its needs, which can be carried out at different stages. It should be noted that the analysis of the enterprise at certain stages is primarily based on the formation of specific and reliable information, and, secondly, it focuses not only on identifying negative phenomena, but also on assessing the positive directions and forms of development of certain activities.

The first stage of the analysis of the enterprise can be described as a rapid analysis, which can be quickly implemented in order to assess the positive and negative factors influencing the activities of the enterprise. Such an analysis can be most successfully performed using the methods of expert survey [2], which have long proven their effectiveness in various sectors of the economy for the rapid solution of production management.

The questionnaire of the expert survey should include "packages" of factors that characterize certain activities and are consistently listed in the questionnaire. Mixing "packages" of factors is not allowed. In the questionnaire of the expert survey, the wording (name) of the factors that evaluate a certain type and type of activity must be unambiguously understood in order to provide a positive or negative answer by the expert. "Packages" of factors for individual activities can be compiled as follows:

- in the group of factors that characterize the production activity, it is recommended to include the following: the quality of the processes of forming the work program, including the procedures of competitive bidding and obtaining a contract; assessment of the qualification level of performers; the need to develop and evaluate the existing production base;

Науково-технічний збірник «АвтомОБІльні доРОГи г доРОжнє БУдІвництво» http://addb.ntu.edu.ua

ISSN 0365-8171 (Print), ISSN 2707-4080 (Online), ISSN 2707-4099 (CD).

AUTOMOBILE ROADS AND ROAD CONSTRUCTION, 2021. Issue 109 
- in the group of factors that characterize the organizational activity may include: quality and timeliness of formation and issuance of production tasks; the quality of design documentation governing work within construction sites; assessment of the level of operational regulation of the use of labor and technical resources; - the factors that characterize the technological activity is recommended to include: assessment of the quality of the material supply system; availability and evaluation of documents regulating technological modes of work performance - technological maps, maps of organization of labor processes; organization and efficiency of the technological control system of production;

- the factors that determine the economic activity of the enterprise can include such as: the level of production at the enterprise; level of mechanization of labor processes; organization of the system of profit formation of production and its use;

- a group of factors that determine financial activities include such as: the effectiveness of the organization of the accounting service; the level of business activity of the enterprise; efficiency of work using the salary fund.

In the documents on the study of expert survey systems there are almost no clear recommendations or methods for determining the required number of factors in the questionnaires of the expert survey or the number of experts who will be engaged in this process. The conducted research and the accumulated experience of the authors in the field of conducting an expert survey indicate that the number of factors in the questionnaire should not exceed $12-15$, which corresponds to the psychological principles of situational assessment of the problem. The title of the questionnaire of the expert survey should correspond to the idea of conducting a comprehensive analysis of the enterprise. For example, the title may look like: A list of factors that affect the efficiency and performance of the enterprise.

The number of experts, as well as the number of factors recorded in the questionnaire of the expert survey, cannot be clearly defined in terms of both the amount and structure of information that experts must have. From the experience of the authors, the number of experts should be 7 - 9 people, which corresponds to the principles of reliability of team management, which is formed by experts. In addition, the odd number corresponds to the principles of preference of a certain group of members of the team of experts, provided that the vote on controversial issues of the survey. On the other hand, if the number of experts is 10 , then this condition significantly speeds up the processing of expert questionnaires. Thus, the number of experts is recommended to accept in the number of $7-10$ specialists with experience and competent to provide answers to the questions in the questionnaire.

Experts' answers are best obtained in the form of a ranked representation of the impact of each factor on the overall result. This means that the expert puts in the questionnaire the rank (number) "1" of the factor that in his opinion is the most important, for example, most determines the negative (or, accordingly, positive) aspects of the enterprise. Rank "2" is assigned to the next factor, which is less important than the factor with rank "1". Thus, the greatest value of ranks is equal to the number of factors (it is not recommended to give individual factors the same ranks!).

Sometimes it may be advisable to conduct an expert survey based on the principles of self-assessment of experts, a separate questionnaire of the expert survey is a symmetrical matrix, where the factors act as experts. Processing of the questionnaire of the expert survey is carried out (including with use of data of the questionnaire of self-assessment of experts) with use of simple arithmetic operations which allow to define average value of a rank of each factor. The obtained information on the average value of the rank of factors is the basis for analyzing the situation of the enterprise. For example, it is possible to build a diagram of the distribution of ranks by factors, which makes it possible to distribute them by groups of influence or by type of activity, which is the basis for providing information on improving certain activities of the enterprise. In general, the rapid analysis of the enterprise on the basis of an expert survey is presented as the simplest and most accessible

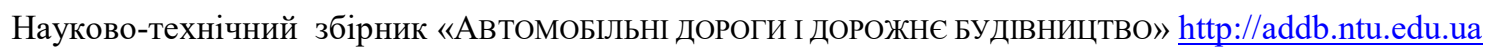
ISSN 0365-8171 (Print), ISSN 2707-4080 (Online), ISSN 2707-4099 (CD). AUTOMOBILE ROADS AND ROAD CONSTRUCTION, 2021. Issue 109 
mechanism for the overall assessment of the enterprise, which does not require for its use or significant resources or time for its implementation.

The information received during carrying out the express - analysis gives the chance to define such directions of activity of the enterprise which need to be improved. A more detailed analysis of activities in such areas can be performed using calculation and analytical methods, which are set out in the relevant government or industry documents and developed in separate sections of applied mathematics.

In this regard, the most developed is the analysis of financial activity of the enterprise, which uses relatively simple approaches [1,3] or serious mathematical models [4] to determine such indicators as, for example, financial stability of the enterprise, its solvency, profitability and others. In our opinion, the assessment of payment flows, comparison and evaluation of the effectiveness of contracts is of special attention. These methods of analysis of financial activity of the enterprise developed in due time are rather actual and verified on scales of their use. But, unfortunately, they are all based on transactions with information that compiles financial statements, or uses statistical approaches to process it. As you know, accounting is the final financial part of the enterprise, and therefore some of the indicators, such as the company's profit "follow" from a rather vague calculation. On the other hand, the use of statistical methods for processing financial information in many cases is a questionable factor due to the effect of autocorrelation of indicators.

At the stage of analysis of the current analysis of the enterprise it is also possible to determine the indicators, which, on the one hand, are quite simple to understand and calculate, and, on the other hand, are quite complex in their interpretation and nature of formation. This can be considered on the examples of calculation of such an indicator as production and the indicator of organizational - technological activity as the level of mechanization.

Thus, the rate of production is traditionally determined by dividing the volume of products obtained over time (in the construction industry in most cases - is the cost of work performed) by the number of contractors. But determining the cost of work performed (or the process of forming contract prices) in construction is still far from perfect, which will be discussed below. In addition, this approach to determining the output does not take into account the intensity of work of performers. Therefore, for the analysis of production should be used quite serious techniques, such as [5], in which the processes of calculating production are estimated by such an indicator as productivity. Unfortunately, the use of such techniques to analyze the rate of production in transport construction companies is quite complex and virtually inaccessible for many reasons.

Determining the indicator of the level of mechanization, which is classically determined by the ratio of the volume of work performed by the mechanized method to the total volume of work, is somewhat problematic. The reason for this is to determine part of the volume of work that is "performed in a mechanized manner." Therefore, the level of mechanization is recommended to be determined by indicators that characterize it, for example, using data on the ratio of labor intensity of machine operators to the total labor intensity of performers or a simple ratio of the number of machine operators to the total number of workers.

But despite the shortcomings of determining some indicators of different activities of the enterprise, the current analysis with their use is quite reasonable, as the values of these indicators are mainly relative in nature, which still provides a basis for assessing trends in certain activities.

It should be noted that in the direction of development of processes of the analysis of current activity of the enterprises of building branch developments of methods of an estimation of prospects of its improvement are conducted. For example, at one time a method was created to determine the production capacity of individual production enterprises of transport construction [6]. Production capacity is the performance of the maximum amount of work of a certain structure under the condition of the best technological use of resources. As a result of determining the production capacity is calculated not only the possible volume of certain types of work in the physical dimension, but also the so-called balances of resources, ie determines the excess resources

Науково-технічний збірник «АВтОмОБІльні дОРОГИ І дОРОЖнє БУдІвницТвО» http://addb.ntu.edu.ua

ISSN 0365-8171 (Print), ISSN 2707-4080 (Online), ISSN 2707-4099 (CD).

AUTOMOBILE ROADS AND ROAD CONSTRUCTION, 2021. Issue 109 
- labor and technical - or their lack of greater employment in the production of existing resources. The advantage of this technique is that for its definition relatively small and absolutely accessible volumes of information are used, namely:

- the number of resources - labor and technical - and the value of the annual working time of each of them (respectively in man. $\mathrm{x}$ hours and machine. $\mathrm{x}$ hours);

- a list of technological processes performed by the enterprise during the year under various contracts, which is registered in the acts of work performed in the form №KБ-2B;

- technologically possible time of each labor process during the year;

- the cost of the unit of measurement of each technological process, which is also an integral part of the acts on the form №KБ-2B;

- normative information on the cost of resources per unit of work, which is an integral part of the Resource Elemental Estimate Standards - RECN - Ресурсні Елементні Кошторисні норми РЕКН).

Calculations of production capacity, and in other words - a rational program of work - are implemented using an algorithm for simulating the processes of employment of resources on individual processes in the order of their priorities, which in turn are calculated without additional source information, which is given above. Cost evaluation of the work program as a whole and its components of technological complexes of works, as well as data on employment during the year of labor and technical resources are used to determine various indicators of organizational, technological and economic activities of the enterprise.

If necessary, in the system of analysis of various activities of the enterprise can be developed special research work. For example, which are related to such pressing issues as determining the real cost of work of individual contracts and determining the actual profit of the enterprise.

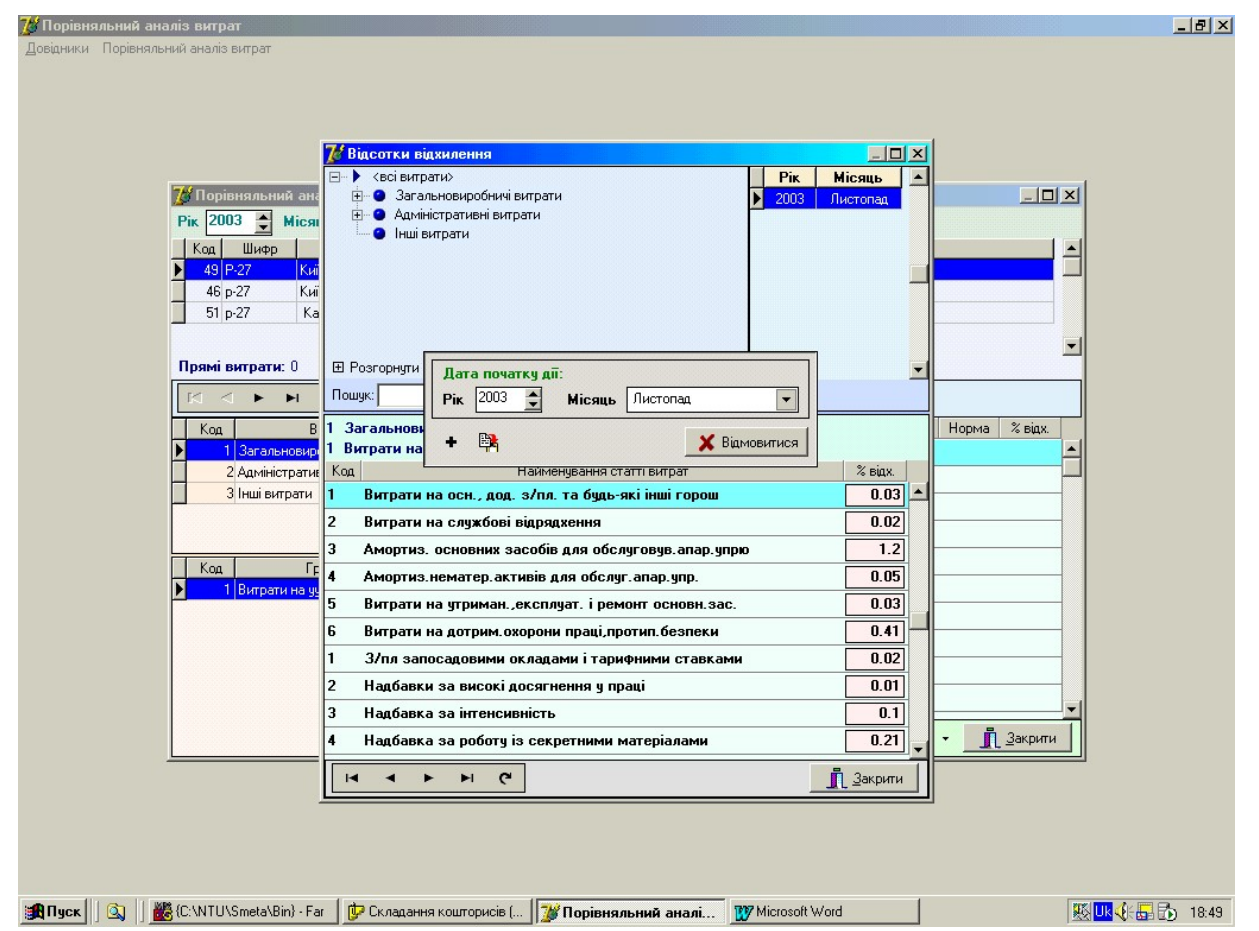

Figure - 1 Scenario of adjustment of tables of conditional norms of percent of expenses

Рисунок - 1 Сценарій коригування таблиць умовних норм відсотків витрат

As is known, since 2000 there is a system of determining the cost of construction works in Ukraine, which is characterized by the use of the so-called comprehensive method of calculations to establish the components of the cost. This means that some elements of value, such as the cost of transporting goods, the cost of operating 
machines and others are calculated in accordance with clear methods of analytical formulas. The other part of the cost elements, such as overhead and administrative costs, profit and the other large part is determined in relation to the total regulatory labor costs through a system of coefficients and monetary factors. Such calculation procedures are also based on a number of guidelines, recommendations and a system of normative documents (JMS). For example, it is "Recommendations for determining funds for customer risk insurance. $\mathrm{P}$ Д.1.1-218-03449261 - 760: 2009 ». But the standard labor costs of workers and machine operators do not correspond to the actual costs, as the employee is in production during the work shift and only part of it this time $(35-45 \%)$ is engaged in work.

Information on possible actual labor costs, which determine the planned costs (or design estimates), could be established provided that the algorithms for determining the elements of the cost of work will be based on data from the design of the production organization within individual facilities. Only in this way can be obtained information on the number of performers of various works and labor processes, data on the terms of their employment and the intensity of resource use during work shifts, information on working conditions. All these data can be used in the development and implementation of an effective method of determining the real cost of the project, which can be called the method of direct calculation.

Implementation of the method of direct calculation of value determination is focused on the development of a number of algorithms for determining its individual elements. Particular attention should be paid to the definition of such elements as overhead and administrative costs, the calculation of which is associated with the formation of data on actual income.

In 2004-2008, with the responsible participation of O.P. Kanin (О.П.Канін), research works on the development of the accounting system, rationing and planning of articles of general production and administrative costs were performed at the request of SJSC Motor Roads of Ukraine. The idea was that in the system of accounts of activity of separate production units of region (area) accounts (on the rights of subaccounts) are entered, each of which corresponds to this or that article of general production and administrative expenses. Then, during payment transactions under a certain item, information is entered into the accounting system. On the basis of the accumulated data on expenses on each article the so-called conditional norms of percent of expenses (fig. 1) which are defined as a share of expenses from the sum of direct expenses are defined. Having such regional conditional norms of percentages of expenses it is possible to calculate both cost of each article of general production or administrative expenses and their general value. This information as planned data is stored in the accounting structure and acts as a cost limit for the relevant items. As a result, the difference between the planned value of each item and the actual costs accumulates the amount of savings that are part of the profit.

Actual profit is defined as the sum of funds, determined by the principles of estimated profit and the amount of accumulated cost savings for all items. Accounting according to the following principles is carried out in the context of: individual contracts; individual performers; individual months. Such a developed accounting system provides a variety of information on the operation of the costs of performing contracts by different performers and serves as a source of analysis of all activities of the enterprise.

\section{Conclusions}

The procedures presented in the article for conducting a comprehensive analysis of the enterprise, consisting of individual stages, outline the general tasks that are solved. Each of the selected stages can be performed independently, but still desirable sequential scheme of their implementation. It should be noted that conducting an effective analysis of any activity of the enterprise requires not only hard work of performers, but also the appropriate qualifications. Therefore, in practice, the analysis of the enterprise is to determine the dynamics of change of a particular indicator over time or in relation to another indicator. Such studies are carried out using simple methods of comparative analysis, statistical studies, graphical methods, etc. But the development of

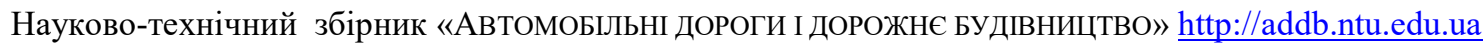

ISSN 0365-8171 (Print), ISSN 2707-4080 (Online), ISSN 2707-4099 (CD).

AUTOMOBILE ROADS AND ROAD CONSTRUCTION, 2021. Issue 109 
modern production increasingly requires an effective analysis of the enterprise on the basis of a systematic approach to this problem and its solution using sound methods.

\section{References}

1. Sheremet AD, Saifulin RS Methods of financial analysis. - M .: INFRA, 1996. - 176.

2. Beshelev SD, Gurvich RG Mathematical and statistical methods of expert assessments. - 2 - is ed. - M .: Статистика, 1980. - 263 с.

3. Rusak NA, Rusak VA Financial analysis of the business entity: Reference manual. - Мн .: Выш.шк., 1997. $-309 \mathrm{c}$.

4. Chetyrkin EM Methods of financial and commercial calculations. - M .: "Delo", "Business Rech", 1992. $320 \mathrm{p}$.

5. Recommendations for integrated planning and analysis of labor productivity in construction / VNIPI labor in construction. - M .: Stroyizdat, 1986. - 88 p.

6. Lipsky GE, Likhostup MM Fundamentals of organization, planning and management of road production: A textbook in two parts. - К .: ГРАНМНА, 2010. - $400 \mathrm{c}$.

\section{ФУНКЦІОНУВАННЯ СИСТЕМИ КОМПЛЕКСНОГО АНАЛІЗУ ДІЯЛЬНОСТІ ВИРОБНИЧОГО ПІДПРИЕМСТВА}

Лихоступ Микола Миколайович, кандидат технічних наук, доцент, доцент кафедри транспортно будівництва та управління майном Національного транспортного університету. e-mail: lichostup5n5@gmail.com, тел.+380662363038, Україна, 01010, м. Київ, вул. Омеляновича - Павленка, 1, кім. 206. https://orcid.org/0000-0001-8139-1768

Горбань Ірина Олегівна, студенка спеціальності підприємництво, торгівля та біржова діяльність по кафедрі транспортного будівництва та управління майном Національного транспортного університету. e-mail: irka.gorban@gmail.com тел. +380668300232, Україна, 01010, м. Київ, вул. Омеляновича - Павленка, 1, кім. 206. https://orcid.org/0000-0002-1254-4772

Анотація. В статті розглянуті основи функціонування системи комплексного аналізу діяльності підприємства, зайнятого в сфері транспортного будівництва, який пропонується реалізувати за трьома етапами. Ідея виділення таких етапів визначає потреби підприємства в отриманні рішень не тільки про поточні недоліки в його діяльності, але також і про позитивні напрямки його розвитку. На кожному із етапів проведення аналізу пропонується використання відносно простих, але ефективних і доступних для працівників підприємства методів. На першому, який в цілому уявляється як експрес - аналіз, використовуються відносно прості експертні методи. На другому етапі, коли мова йде про аналіз поточної діяльності підприємства, рекомендується використання розрахунково - аналітичних методів, які розвинуті в офіційних методиках та рекомендаціях. Третій етап - це етап проведення науково - практичних робіт та досліджень, які спрямовані на отримання важливих рішень в сфері суттєвої зміни та покращання діяльності підприємства. Кожен етап аналізу діяльності підприємства демонструється в статті прикладами вирішення його складових задач.

Ключові слова: підприємство, комплексний аналіз, етапи, методи, алгоритми рішень.

\section{Перелік посилань}

1.Шеремет А.Д., Сайфулин Р.С. Методика финансового анализа. - М.: ИНФРА, 1996. - 176.

2.Бешелев С.Д., Гурвич Р.Г. Математико-статистические методы экспертных оценок. -2 - е изд. - М.: Статистика, 1980. - 263 с.

3.Русак Н.А., Русак В.А. Финансовый анализ субъекта хозяйствования: Справочное пособие. Мн.: Выш.шк., 1997. - 309 с.

4.Четыркин Е.M. Методы финансовых и коммерческих расчетов. - М.: «Дело», «Business Речь», 1992. $-320 \mathrm{c}$.

5.Рекомендации по комплексному планированию и анализу производительности труда в строительстве /ВНИПИ труда в строительстве. - М.: Стройиздат, 1986. - 88 с.

6.Ліпський Г.Є., Лихоступ М.М. Основи організації, планування та управління дорожнім виробництвом: Підручник у двох частинах. - К.: ГРАНМНА, 2010. - 400 с. 